\title{
Efektivitas Kasasi Demi Kepentingan Hukum Dalam Sistem Peradilan Pidana
}

\author{
Muhammad Ridha \\ Magister Hukum Fakultas Hukum Universitas Islam Indonesia Yogyakarta Indonesia \\ Jln. Cik Di Tiro No. 1 Yogyakarta Indonesia \\ ridhamuh96@gmail.com
}

\begin{abstract}
This study aims to analyze the effectiveness of extraordinary cassation legal remedies for the sake of the law and examine the revitalization of extraordinary cassation legal remedies for legal purposes in the future criminal justice system. This research is a normative juridical law research that uses a statutory approach to analyze the legal issues raised. The results of this study indicate that first, the ineffectiveness of legal remedies in the form of cassation for the sake of the law is caused by the substance of the article that regulates the legal remedies that are essentially aimed at protecting and safeguarding the rights of the convict. Second, the effort to revitalize the Criminal Procedure Code is aimed at making extraordinary legal efforts in the form of cassation for the sake of the law run effectively, namely by returning the right to legal remedies for cassation for the sake of the law to the public prosecutor, and revising the article that became the root of the problem of ineffectiveness.
\end{abstract}

Key Words: Cassation for the Interest of the law, criminal justice system, effectivity

\begin{abstract}
Abstrak
Penelitian ini bertujuan untuk menganalisis efektifitas upaya hukum luar biasa kasasi demi kepentingan hukum dan mengkaji revitalisasi upaya hukum luar biasa kasasi demi kepentingan hukum dalam sistem peradilan pidana yang akan datang. Penelitian ini merupakan penelitian hukum yuridis normatif yang menggunakan pendekatan perundang-undangan untuk menganalisis permasalahan hukum yang diangkat. Hasil penelitin ini menyimpulkan bahwa pertama, ketidakefektifan upaya hukum berupa kasasi demi kepentingan hukum disebabkan oleh substansi pasal yang mengatur upaya hukum tersebut pada hakekatnya bertujuan melindungi dan menjaga hak terpidana. Kedua, upaya merevitalisasi kembali Kitab Hukum Acara Pidana bertujuan agar upaya hukum luar biasa berupa kasasi demi kepentingan hukum dapat berjalan efektif, yaitu dengan cara mengembalikan hak upaya hukum kasasi demi kepentingan hukum tersebut kepada jaksa penuntut umum, dan merevisi pasal yang menjadi akar permasalahan ketidakefektifan tersebut.
\end{abstract}

Kata-kata Kunci: Efektivitas; kasasi demi kepentingan hukum; sistem peradilan pidana 


\section{Pendahuluan}

Indonesia sebagai negara hukum telah menjamin warga negaranya berhak atas pengakuan, jaminan, perlindungan dan kepastian hukum yang adil serta perlakuan yang sama dihadapan hukum, sebagaimana diatur dalam Konstitusi Pasal 28D ayat (1) Undang-Undang Dasar Republik Indonesia Tahun 1945. Artinya, Indonesia sebagai negara hukum, terutama dalam arti mateiil, melihat bahwa hukum itu bukan hanya yang secara formal ditetapkan oleh lembaga legislatif, melainkan yang memiliki nilai keadilannya dijadikan hal penting. ${ }^{1}$ Oleh karena itu, dapat dikatakan bahwa hukum yang secara formal belum tentu mempunyai nilai-nilai keadilan sehingga untuk mencapai nilai keadilan dalam hal ini hakim dituntut untuk dapat menggali nilai-nilai dan rasa keadilan yang tumbuh dan hidup dalam masyarakat.

Perlindungan terhadap segenap bangsa Indonesia melalui perangkat hukum merupakan hal mutlak yang harus diwujudkan sehingga tidak ada artinya melindungi segenap bangsa dan tumpah darah jika ternyata masih ada penderitaan dirasakan rakyat berupa ketimpangan hak yang mencerminkan ketidaksejahteraan dan keadilan seluruh rakyat Indonesia. ${ }^{2}$ Hal tersebut terjadi salah satunya disebabkan penegakan hukum tidak dilandasi oleh perangkat hukum yang tidak berorientasi pada nilai keadilan. ${ }^{3}$

Penegakan hukum merupakan salah satu cara untuk menciptakan tata tertib, keamanan dan ketentraman di masyarakat, sebagai usaha pencegahan maupun pemberantasan atau penindakan setelah terjadinya pelanggaran hukum. ${ }^{4}$ Penegakan hukum merupakan tugas negara yang salah satu perwujudan dengan membentuk lembaga peradilan yang sekaligus diharapkan dapat melakukan koreksi dan rekoreksi terhadap hukum positif yang berlaku sesuai perkembangan zaman yang diharapkan dapat mencerminkan nilai keadilan. ${ }^{5}$ Jadi, hakim dalam memutus harus mengandung rasa keadilan bagi masyarakat. Namun dalam prakteknya, kekeliruan dan kekhilafan hakim dalam suatu putusan bukti nyata bahwa hakim sebagai manusia yang tidak luput dari kesalahan. Oleh sebab itulah dalam sistem peradilan pidana seseorang terpidana dijamin haknya untuk mendapatkan pembelaan dan melakukan pembelaan sejak

\footnotetext{
${ }^{1}$ Moh. Mahfud MD., Membangun Politik Hukum, Menegakean Konstitusi, Pustaka LP3ES, Jakarta, 2006, hlm. 187-188

2 Ridwan, Kebijakan Penegakan Hukum Pidana Dalam Pemberantasan Tindak Pidana Korupsi di Indonesia, Jurnal Jure Humano, Volume Nomor 1, 2009, hlm. 74

3 Dahlan, Problematika Keadilan Dalam Penerapan Pidana Terhadap Penyalahgunaan Narkotika, Deepublish, Yogyakarta, 2017, hlm. 1

${ }^{4}$ Ratna Nurul Aflah, Barang Bukti Dalam Proses Pidana, Sinar Grafika, Jakarta, 2002, hlm. 6

5 Op. Cit., Problematika Keadilan Dalam Penerapan Pidana Terbadap Penyalahgunaan Narkotika, Deepublish, Yogyakarta, 2017, hlm. 2
} 
tahap penyidikan hingga tahap pengajuan peninjauan kembali ke Mahkamah Agung, bahkan upaya hukum guna membela hak-hak terpidana merupakan hak yang vital dan dijamin dalam perlindungan Hak Asasi Manusia.

Sistem peradilan pidana membuka ruang bagi para pihak yang berperkara untuk tidak menerima putusan atau untuk membela diri dari putusan hakim yang dinilai tidak sesuai yang diharapkannya yakni berupa upaya hukum. Upaya hukum merupakan sarana untuk melaksanakan hukum, yaitu hak terpidana atau jaksa penuntut umum untuk tidak menerima penerapan atau putusan-putusan pengadilan karena tidak merasa puas dengan penetapan atau putusan tersebut. ${ }^{6}$ Terkait hal ini, Pasal 1 butir 12 KUHAP menyatakan bahwa hak terdakwa atau penuntut umum untuk tidak menerima putusan pengadilan yang berupa perlawanan atau banding atau kasasi atau hak terpidana untuk mengajukan permohonan peninjauan kembali dalam hal serta menurut cara yang diatur dalam undang-undang. ${ }^{7}$

Upaya hukum yang diatur dalam KUHAP dibagi menjadi dua bagian yakni, upaya hukum biasa yang meliputi banding dan kasasi, serta upaya hukum luar biasa berupa kasasi demi kepentingan hukum dan peninjauan kembali. Upaya hukum luar biasa merupakan pengecualian dan penyimpangan dari upaya hukum biasa, upaya banding dan kasasi. ${ }^{8}$ Dalam kaitannya dengan upaya hukum selain hak terpidana, jaksa penuntut umum juga diberi hak untuk tidak menerima putusan-putusan pengadilan yang dinilai tidak sesuai dengan apa yang diharapkan yaitu upaya hukum luar biasa berupa kasasi demi kepentingan hukum (selain banding dan kasasi).

Upaya hukum luar biasa yaitu kasasi yang diajukan demi kepentingan hukum yang diatur dalam KUHAP pada bab XVIII bagian kesatu dari Pasal 259 sampai Pasal 262 KUHAP. Kasasi tersebut dapat diajukan terhadap semua putusan yang telah memperoleh kekuatan hukum tetap yang hanya dapat diajukan jaksa penuntut umum. Tujuan jaksa penuntut umum mengajukan kasasi tersebut adalah untuk menjaga kepentingan terpidana, sebab putusan kasasi demi kepentingan hukum tidak boleh merugikan pihak yang berkepentingan (terpidana) dimana hukuman yang akan dijatuhkan oleh Mahkamah Agung atas permintaan kasasi demi kepentingan hukum oleh jaksa penuntut umum tidak

\footnotetext{
hlm. 3

${ }^{6}$ Andi Hamzah, Irdan Dahlan, Upaya-Upaya Hukum Dalam Perkara Pidana, Bina Aksaran, Jakarta, 1987,

7 Andi Sofyan dan Abdul Asis, Hukum Acara Pidana Suatu Pengantar, Prenamedia Group, Jakarta, 2014, hlm. 268. lihat juga Undang-Undang No 8 Tahun 1981 tentang Kitab Undang-Undang Hukum Acara Pidana Pasal 1 butir 12

8 M. Yahya Harahap, Pembahasan Permasalahan dan Penerapan KUHAP, Pemeriksaan Sidang Pengadilan, Banding, Kasasi, Peninjauan Kembali, Sinar Grafika, Jakarta, 2012, hlm. 607
} 
boleh lebih berat dari hukuman semula yang telah dijatuhi dan mempunyai kekuatan hukum yang tetap. ${ }^{9}$

Pada dasarnya ketentuan upaya hukum kasasi demi kepentingan hukum didapatkan dari sistem hukum Belanda, yang mana jika disandingkan dengan kewenangannya, tentu tidak dimiliki oleh kejaksaan selaku penuntut, namun dimiliki oleh kejaksaan pada Mahkamah Agung (parket bij de hoge raad) seakanakan seperti lembaga yang dipimpin oleh jaksa agung (procureur generaal). Lembaga parket bij de hoge raad atau biasa disebut kejaksaan pada Mahkamah Agung ini tidak memiliki fungsi penuntutan yang mana berbeda dengan kejaksaan agung yang memiliki fungsi sebagai penuntut.

Lembaga kejaksaan pada Mahkamah Agung diberi pengecualian khusus terhadap kejahatan berat yang dilakukan oleh kerajaan atau pejabat negara dengan proses penuntutannya langsung dihadapan Mahkamah Agung (forum privilegiatum). Di samping itu, lembaga parket bij de hoge raad mempunyai kewenangan utama berupa memberikan pendapat hukum kepada Mahkamah Agung dalam setiap perkara kasasi. Dengan demikian, kasasi demi kepentingan hukum (cassatie in het belang der wet) dapat juga menjadi penuntut jika terdapat hakim yang melakukan pelanggaran berat yang dapat berakibat pemberhentian jabatan dan untuk perkara pidana dilakukan penuntutan oleh jaksa yang berada Menteri Kehakiman. ${ }^{10}$

Kasasi demi kepentingan hukum merupakan upaya hukum terakhir yang dapat dilakukan oleh Jaksa Penuntut Umum dalam Sistem Peradilan Pidana. Namun dalam perjalanannya, semenjak diaturnya kasasi demi kepentingan hukum didalam KUHAP, ternyata tidak begitu efektif. Hal ini terlihat dari beberapa putusan pengadilan yakni putusan No.186 K/Kr/1979 dan putusan No. $1828 \mathrm{~K} / \mathrm{Pid} / 1989^{11}$, yaitu Jaksa Penuntut Umum memilih upaya hukum biasa yakni kasasi, bahkan Jaksa Penuntut Umum dapat melampaui aturan dalam KUHAP yaitu upaya hukum luar biasa berupa peninjauan kembali.

Beberapa putusan pengadilan yang mengabulkan Jaksa Penuntut Umum melakukan upaya hukum peninjauan kembali yakni untuk pertama kalinya Mahkamah Agung menerima peninjauan kembali oleh Jaksa Penuntut Umum dengan terdakwa Muchtar Pakpahan yang Nomor Perkara: 55K/Pid/1996, 25 Oktober 1996, kemudian putusan perkara Pollycarpus No. 109 PK/Pid/2007 serta

${ }^{9}$ Op. Cit., hlm.287-288

${ }^{10}$ Monica Sara Konardi, “Upaya Hukum Kasasi Demi Kepentingan Hukum Di Indonesia”, Jurnal Hukum Universitas Atma Jaya, Yogyakarta, 2017, hlm. 4-5 di akses melalui website http://ejournal.uajy.ac.id/12142/1/JURNAL\%20HK11433.pdf pada tanggal 25 Deseber 2020 pukul 18.00

https://www.google.com/amp/s/krupukulit.com/2013/03/19/tinjauan-kritis-atas-peran-kepalakejaksaan-tinggi-dalam-upaya-hukum-di-dalam-ruu-kuhap/amp di akses pada pukul 0.30 tanggal 02 januari 2021 
putusan perkara Djoko Tjandra No. 12 PK/Pid.Sus/2009. Ini menunjukkan Jaksa Penuntut Umum tidak mematuhi pedoman hukum acara mengingat sudah jelas secara limitatif yang dapat mengajukan upaya hukum peninjauan kembali yakni terpidana dan ahli warisnya. Selain itu, jika ditinjau lagi dimana Jaksa Penuntut Umum yang mengajukan upaya hukum luar biasa yakni peninjauan kembali, semestinya menggunakan instrumen upaya hukum kasasi demi kepentingan hukum. Oleh sebab itulah penulis ingin menganalisis lebih dalam terkait efektivitas upaya hukum luar biasa kasasi demi kepentingan hukum dalam sistem peradilan pidana.

\section{Rumusan Masalah}

Pertama, bagaimana efektivitas upaya hukum luar biasa kasasi demi kepentingan hukum dalam sistem peradilan pidana? Kedua, bagaimana merevitalisasikan upaya hukum luar biasa kasasi demi kepentingan hukum dalam sistem peradilan pidana yang akan datang?

\section{Tujuan Penelitian}

Pertama, untuk mengetahui efekrivitas upaya hukum luar biasa demi kepentingan hukum dalam sistem peradilan pidana. Kedua, untuk merevitalisasikan upaya hukum luar biasa kasasi demi kepentingan hukum dalam sistem peradilan pidana yang akan datang.

\section{Metode Penelitian}

Penelitian ini merupakan penelitian hukum normatif dengan pendekatan penelitian yang digunakan adalah pendekatan perundang-undangan (statute approach). ${ }^{12}$ Data penelitian ini diperoleh melalui studi kepustakaan dan studi dokumen yang kemudian dianalisis secara kualitatif.

\section{Hasil Penelitian dan Pembahasan}

Efektivitas Upaya Hukum Luar Biasa Kasasi Demi Kepentingan Hukum dalam Sistem Peradilan Pidana

Sistem peradilan pidana merupakan sebuah lembaga yang memerankan fungsinya sebagai sarana menyelesaikan konflik antara kedua pihak, dan juga menegakkan kebenaran dan keadilan. ${ }^{13}$ Pada hakekatnya, sistem peradilan

\footnotetext{
12 Peter Mahmud Marzuki, Penelitian Hukum, Kencana, Jakarta, 2009, hlm. 22

13 Mahrus Ali, "Sistem Peradilan Pidana Progresif: Alternatif Dalam Penegakan Hukum Pidana", Jurnal Hukum, Vol. 14 No. 2, 2007, hlm. 211
} 
pidana identik dengan sistem penegakan hukum pidana ${ }^{14}$, dimana untuk menjalankan fungsinya, sistem peradilan pidana memerlukan beberapa sub sistem yang saling berkaitan yakni sub kepolisian, sub kejaksaan dan sub pengadilan yang akan menanggulangi kejahatan serta mengendalikan terjadinya kejahatan, agar berada dalam batas-batas toleransi yang dapat diterimanya. ${ }^{15}$

Setelah disepakatinya sistem peradilan pidana sebagai sarana menyelesaikan sebuah konflik, tentu memerlukan pedoman dalam menjalankan fungsinya agar tidak terjadi kesewenang-wenangan antara penegak hukum dengan masyarakat sipil (pihak yang berkepentingan). Dari sinilah pemerintah membentuk sebuah aturan atau pedoman pagi para penegak hukum yang berada dalam ranah sistem peradilan pidana agar berada dalam batasan-batasan yang diberikan oleh perundang-undangan.

Di dalam menegakkan dan mewujudkan keadilan, kepastian dan kemanfaatan hukum, tindakan penegak hukum secara formal harus ada pengaturannya agar tindakannya tidak kontradiktif dengan undang-undang, yaitu tidak hanya mengacu kepada ketentuan hukum pidana materiil (KUHP), namun juga perlu mengacu pada hukum pidana formil. Hukum pidana formil tersebut diatur dalam Undang-Undang Nomor 8 Tahun 1981 tentang Kitab Undang-Undang Hukum Acara Pidana (KUHAP) yang mengatur ketentuanketentuan suatu proses beracara dalam rangka penegakan hukum pidana materiil (KUHP).

Moeljatno yang menyatakan bahwa hukum acara pidana merupakan bagian dari keseluruhan hukum yang berlaku di suatu negara yang memberikan dasardasar dan aturan yang menentukan dengan cara dan prosedur macam apa ancaman pidana yang ada pada suatu perbuatan pidana dapat dilaksanakan apabila ada sangkaan bahwa orang telah melakukan delik tersebut. ${ }^{16}$ Jadi, hukum acara pidana digunakan untuk menegakkan, mempertahankan atau menjaga agar ketentuan hukum pidana materiil dapat dilaksanakan mengingat tanpa adanya hukum acara pidana, ketentuan hukum pidana materiil hanya merupakan ketentuan tertulis yang kosong belaka atau menjadi peraturan yang mati. ${ }^{17}$

Lahirnya KUHAP tersebut menggantikan Het Herziene Inlandsch Reglement (HIR) sebagai payung hukum acara pidana di Indonesia mengingat kejamnya aturan dalam HIR seperti penangkapan yang berkepanjangan tanpa akhir,

\footnotetext{
${ }^{14}$ Barda Nawawi Arief, Kapita Selekta Hukum Pidana Tentang Sistem Peradilan Pidana Terpadu, BP Universitas Diponegoro, Semarang, 2007, hlm. 19-26

15 Mardjono Reksodiputro, Kriminologi dan Sistem Peradilan Pidana, Cet Pertama, Buku Kedua, Pusat Pelayanan Keadilan dan Pengabdian Hukum Universitas Indonesia, Jakarta, 1994, hlm. 140

16 Moeljatno, Azaz-Azaz Hukum Pidana, Bina Aksara, Jakarta, 1995, hlm. 1-6

${ }^{17}$ Didik Edro Purwoleksono, Hukum Acara Pidana, Airlangga University Press, Surabaya, 2015, hlm. 13
} 
penahanan tanpa surat perintah, dan tanpa penjelasan kejahatan yang dituduhkan, serta aturan pemerasan atau pengakuan secara paksaan. ${ }^{18}$ Oleh karena itu, Kehadiran KUHAP bertujuan untuk mengoreksi pengalaman praktik peradilan masa lalu yang penuh dengan kesesatan yang tidak sejalan dengan hak asasi manusia, sekaligus memberi legislasi hak asasi manusia kepada tersangka ataua terdakwa untuk membela kepentingannya di dalam proses hukum. KUHAP yang berlaku sekarang ini mengatur mulai dari penyelidikan, penyidikan, penuntutan, peradilan, acara pemeriksaan, banding di Pengadilan Tinggi, serta kasasi di Pengadilan Negeri dan juga peninjauan kembali ke Mahkamah Agung. ${ }^{19}$

KUHAP mengatur ketentuan terkait upaya hukum dalam Bab XVII dan XVIII KUHAP. Upaya hukum merupakan segala usaha untuk mencapai tujuan hukum benar-benar berjalan sebagaimana mestinya dan untuk mencegah adanya kekeliruan atau kekhilafan hakuim dalam suatu keputusan hakim. ${ }^{20}$ Sudikno Mertokusumo mengemukakan upaya hukum atau alat untuk mencegah atau memperbaiki kekeliruan dalam suatu putusan. ${ }^{21}$ Dengan demikian, upaya hukum diberikan kepada tersangka/terpidana dan juga penuntut umum untuk tidak menerima atau melakukan perlawanan terhadap putusan hakim secara berjenjang atau bertingkat berdasarkan ketentuan yang telah ditetapkan oleh undangundang. ${ }^{22}$

Upaya hukum yang telah ditetapkan oleh undang-undang ada dua jenis, pertama, upaya hukum biasa yang terdiri dari banding dan kasasi, kedua, upaya hukum luar biasa berupa kasasi demi kepentingan hukum dan peninjauan kembali. ${ }^{23}$ Upaya hukum biasa adalah upaya hukum terhadap keputusan yang belum dilaksanakan dan penggunaan salah satu dari upaya hukum itu dapat menangguhkan eksekusi hukuman. Sedangkan upaya hukum luar biasa dapat ditempuh setelah upaya-upaya hukum lainnya telah dipergunakan sehingga putusan pengadilan dapat dilaksanakan. ${ }^{24}$

Muhammad Taufik Makarao dan Suhasril memiliki pendapat yang berbeda terkait dengan upaya hukum tersebut, yaitu pertama, upaya hukum biasa diajukan terhadap putusan pengadilan yang belum mempunyai kekuatan hukum tetap, sedangkan upaya hukum luar biasa diajukan terhadap putusan pengadilan

\footnotetext{
${ }^{18}$ Ibid., hlm. 48-49

19 Andi Sofyan dan Abd Asis, Hukum Acara Pidana Suatu Pengantar, Edisi Kedua, Kencana, Jakarta, 2014, hlm. 48

20 Ramiyanto, Upaya-Upaya Hukum Perkara Pidana Di Dalam Hukum Positif dan Perkembangannya, Citra Aditya Bakti, Bandung, 2019, hlm. 5

${ }^{21}$ Ibid., hlm. 7

${ }^{22}$ Rocky Marbun, Deni Bram dkk, Kamus Hukum Lengkap, Transmedia Pustaka, Jakarta, 2012, hlm. 322

${ }^{23}$ Ibid

${ }^{24}$ Op. Cit., Ramiyanto, Upaya-Upaya Hukum Perkara Pidana..., hlm. 11
} 
yang telah mempunyai kekuatan hukum tetap. Kedua, upaya hukum biasa tersebut tidak memerlukan syarat-syarat yang bersifat khusus atau syarat-syarat tertentu, sedangkan upaya hukum luar biasa hanya dapat diajukan dengan syarat-syarat khusus atau syarat-syarat tertentu. Ketiga, upaya hukum biasa tidak selamanya ditujukan ke Mahkamah Agung, sedangkan upaya hukum luar biasa diajukan kepada Mahkamah Agung dan diperiksa serta diputus Mahkamah Agung sebagai instansi pertama dan terakhir..$^{25}$

Upaya hukum biasa, sebagaiman disebutkan di atas, dilakukan pada pengadilan tingkat pertama (banding) dan pengadilan tingkat tinggi (kasasi), dan upaya hukum luar biasa dilakukan pada tingkat Mahkamah Agung. Namun dalam pembahasan ini lebih kepada upaya hukum luar biasa yakni kasasi demi kepentingan hukum. Kasasi demi kepentingan hukum merupakan salah satu dari upaya hukum luar biasa, yang mana merupakan pengecualian dari upaya hukum biasa. Upaya ini diajukan terhadap putusan pengadilan yang telah mempunyai kekuatan hukum yang tetap. ${ }^{26}$

Kasasi demi kepentingan hukum merupakan hak yang dapat diajukan oleh Jaksa Penuntut Umum yang telah memperoleh kekuatan hukum tetap, kecuali terhadap putusan Mahkamah Agung. Secara formal kasasi demi kepentingan hukum diatur dalam Pasal 259 KUHAP, yang menentukan bahwa demi kepentingan hukum terhadap semua putusan yang telah memperoleh kekuatan hukum tetap dari pengadilan lain selain dari pada Mahkamah Agung, dapat diajukan satu kali permohonan kasasi oleh Jaksa Agung. Selain itu, putusan kasasi demi kepentingan hukum tidak boleh merugikan pihak yang berkepentingan. ${ }^{27}$

Definisi pihak kepentingan di dalam pasal tersebut masih abu-abu mengingat dalam konsideran KUHAP, pihak yang berkepentingan disini selain terdakwa juga Jaksa Penuntut Umum. Terkait hal ini, untuk mencari siapa sebenarnya pihak yang berkepentingan yang diatur dalam pasal tersebut, M. Yahya Harahap mengemukakan bahwa pihak yang berkepentingan ada pada terpidana yang tidak boleh dirugikan putusan kasasi demi kepentingan hukum..$^{28}$ Lebih lanjut Adami Chazawi berpendapat bahwa kasasi demi kepentingan hukum tidak boleh mengubah amar putusan pembebasan menjadi pemidanaan, termasuk juga putusan lepas dari segala tuntutan hukum. ${ }^{29}$ Jadi, yang menjadi

25 Ibid

${ }^{26}$ YLBHI dan PSHK, Panduan Bantuan Hukum di Indonesia, YLBHI, Jakarta, 2007, hlm. 252

${ }^{27}$ Ibid, lihat juga penjelasan Kitab Undang-Undang Hukum Acara Pidana pada Pasal 259

${ }_{28}$ M. Yahya Harahap, Pembahasan Permasalahan dan Penerapan KUHAP (Pemeriksaan Sidang Pengadilan, Banding, kasasi dan Peninjauan Kembali), Sinar Grafika, Jakarta, 2012, hlm. 610

${ }_{29}$ Adami Chazawi, Lembaga Peninjauan Kembali (PK) Perkara Pidana (Penegakan Hukum Dalam Penyimpangan Praktik \& Peradilan Sesat), Sinar Grafika, Jakarta, 2011, hlm. 107 
pointnya yakni kasasi demi kepentingan hukum ini semata-mata hanya kepentingan hukum agar menjadikan satu kesatuan penafsiran undang-undang serta adanya kesatuan dalam cara melaksanakan undang-undang. ${ }^{30}$

Didalam perjalanannya, upaya hukum kasasi demi kepentingan hukum ini tidak berjalan begitu efektif sebagaimana upaya hukum lainnya yang diatur di dalam KUHAP. Ketidakefektifan kasasi demi kepentingan hukum ini bisa dilihat dari historisnya yang dimana digunakan hanya beberapa kali, yaitu putusan pengadilan yakni putusan No.186 K/Kr/1979 dan putusan No. 1828 K/Pid/198931, Penuntut Umum memilih upaya hukum biasa yakni kasasi, bahkan Jaksa Penuntut Umum dapat melampaui ketentuan didalam KUHAP, yakni upaya hukum luar biasa berupa peninjauan kembali.

Ketidakefektifan upaya hukum luar biasa berupa kasasi demi kepentingan hukum ini bukan karena tidak banyaknya perkara yang dapat diajukan kasasi demi kepentingan hukum mengingat sangat banyak putusan pengadilan tingkat pertama maupun banding yang dapat diajukan kasasi demi kepentingan hukum. ${ }^{32}$ Misalnya yaitu kasus Djoko Tjandra yang diadili di Pengadilan Negeri Jakarta Selatan, yang mana amar putusanya membebaskan Djoko Tjandra, lalu Jaksa Penuntut Umum menolak putusan Pengadilan Negeri dan melakukan upaya hukum biasa yakni banding kepada Pengadilan Tinggi, namun hasil putusanya juga senada dengan Pengadilan Negeri yakni bebas, kemudian Jaksa Penuntut Umum kembali mengajukan kasasi kepada Mahkamah Agung dan hasil putusannya juga menguatkan putusan sebelumnya. ${ }^{33}$ Selanjutnya, Jaksa Penuntut Umum mengajukan peninjauan kembali terhadap putusan pembebasan Djoko Tjandra dalam kasus korupsi cessie Bank Bali dimana hakim menjatuhkan vonis 2 tahun dan denda 15 juta dengan hukuman tambahan perampasan uang sebesar Rp. 546.000.000.000,00.34

Pemaparan kasus di atas menunjukkan bahwa Jaksa Penuntut Umum lebih memilih mengajukan upaya hukum peninjauan kembali daripada menggunakan upaya hukum kasasi demi kepentingan hukum, sebagaimana yang disampaikan oleh Andi M. Taufik (Kasubdit Upaya Hukum, Eksekusi dan Eksaminasi pada Jampidum Kejagung RI) bahwa, terhadap putusan bebas atau lepas dari segala tuntutan hukum, dalam pratiknya Jaksa Agung cq Jaksa/Penuntut Umum tidak

30 Andi Hamzah dan Irdan Dahlan, Upoya-Upaya Hukum Dalam Perkara Pidana, Bina Aksara, Jakarta, 1987,

31 https://www.google.com/amp/s/krupukulit.com/2013/03/19/tinjauan-kritis-atas-peran-kepalakejaksaan-tinggi-dalam-upaya-hukum-di-dalam-ruu-kuhap/amp di akses pada pukul 0.30 tanggal 02 januari 2021

32 Ibid

33 Aqshal Muhammad Arsyah, Cora Kristin Mulyani dkk, Kajian Labirin Hukum Penyelesaian Kasus Djoko Tjandra, Dewan Mahasiswa Justicia Fakultas Hukum UGM, Yogyakarta, 2020, hlm. 6-7 ${ }^{34}$ Ibid 
menggunakan haknya berupa kasasi demi kepentingan hukum dan lebih menggunakan upaya hukum luar biasa yakni peninjauan kembali. Hal ini dikarenakan Jaksa/Penuntut Umum berpendapat bahwa semua unsur pasal yang didakwakan kepada terdakwa telah dapat dibuktikan di depan persidangan sehingga harus ada pemidanaan terhadap terdakwa bukan putusan bebas atau lepas dari segala tuntutan hukum ${ }^{35}$ Hal inilah yang menjadikan tidak efektif upaya hukum kasasi demi kepentingan hukum, dimana seharusnya bisa digunakan sebagai senjata pamungkas bagi Jaksa Penuntut Umum untuk melakukan upaya hukum atas putusan pengadilan terdahulu yang dinilai tidak menerapkan hukum sebagaimana mestinya dan mungkin juga adanya kekhilafan hakim, justru jaksa penuntut umum lebih memilih untuk menempuh upaya hukum terakhir yakni peninjauan kembali.

Ketidakefektifan kasasi demi kepentingan hukum tersebut terletak pada substansi kasasi demi kepentingan hukum itu sendiri yang mana dalam hirarkinya bertujuan melindungi dan menjaga hak terpidana. ${ }^{36}$ Dalam artian bahwa putusan kasasi demi kepentingan hukum tidak boleh merugikan pihak terpidana sehingga putusan pengadilan yang berupa pemidanaan, pembebasan atau pelepasan dari segala tuntutan hukum tidak akan berubah, meskipun putusan-putusan tersebut setelah dilakukan pemeriksaan kasasi demi kepentingan hukum oleh Mahkamah Agung kemudian ternyata dianggap sebagai tidak benar, khususnya dalam kasus Djoko Tjandra yang pada pengadilan negeri sampai pengadilan tinggi dan di perkuat putusanya di Mahkamah Agung dengan pembebasan, namun dalam dakwaan Jaksa Penuntut Umum telah membuktikan Djoko Tjandra terbukti melakukan tindak pidana korupsi, sehingga upaya hukum kasasi demi kepentingan hukum tidak dapat merubah putusan tersbut. ${ }^{37}$ Oleh sebab itulah penyebab dari ketidakefektifan instrumen ini (kasasi demi kepentingan hukum) beranjak dari putusan bebas di tingkat judex facti yang dipandang mengandung kesalahan sehingga jaksa penuntut umum dianggap tidak perlu mengajukan kasasi demi kepentingan umum yang pada akhirnya tidak memiliki dampak apapun terhadap terdakwa. Jadi, penyebab jaksa penuntut umum tidak melakukan kewenangannya berupa upaya hukum kasasi demi kepentingan umum adalah ketentuan didalam KUHAP yang mengatur hal tersebut masih kurang jelas sehingga menghambat terwujudnya keadilan, kemanfaatan dan kepastian hukum.

35 Ristu Darmawan dalam Tesisnya, Upaya Hukum Luar Biasa Peninjauan Kembali Terbadap Putusan Bebas Dalam Perkara Pidana, Universitas Indonesia, Jakarta, 2012, hlm. 112

36 Op. Cit., YLBHI dan PSHK, Panduan Bantuan Hukum di Indonesia, hlm. 252

37 Op. Cit., Ramiyanto, Upaya-Upaya Hukum Perkara Pidana..., hlm. 105 


\section{Revitalisasi Upaya Hukum Luar Biasa Kasasi Demi Kepentingan Hukum dalam Sistem Peradilan Pidana Mendatang}

Hukum acara pidana merupakan pedoman penegak hukum dalam beracara di peradilan di Indonesia yang disusun dengan persistensi yang tinggi untuk ditepati kepastian hukumnya sehingga sering dipandang sebagai hukum yang statis dan tidak memerlukan dinamisasi dalam penegakannya. Secara sederhananya, sistem peradilan pidana ini dibelenggu oleh legalistik-positivistik, yaitu penegak hukum akan terpaku pada apa yang sudah ditentukan dalam undang-undang sehingga hakim hanya sebagai corong undang-undang saja.

Kemungkinan adanya ketidakjelasan pasal didalam perundang-undangan tersebut yang saling kontradiktif dapat menyebabkan putusan hakim yang mengandung ketidakpastian dan keadilan serta kemanfaatan hukum. Hal ini dipertegas dengan adanya kritik, baik dari kalangan akademisi maupun praktisi, atas putusan hakim yang mana dinilai tidak memberikan rasa keadilan, kepastian serta kemanfaatan hukum, padahal akar permasalahan itu sendiri muncul karena ketidakjelasan norma yang saling kontradiktif antara satu sama yang lain. ${ }^{38}$ Oleh sebab itu, bisa kita lihat bahwa berbicara mengenai kepastian, keadilan dan kemanfaatan hukum tidak hanya dilihat dari putusan hakim melainkan juga melihat dari kejelasan norma dan ketegasan dalam sebuah peraturan perundangundangan.

Jeremy Betham menyatakan, bahwa maximizing happines and minimizing pains yang artinya peraturan perundang-undangan harus konsisten, pelaksanaannya jelas, sederhana dan ditegakkan secara tegas sehingga hukum tanpa nilai kepastian hukum akan kehilangan makna karena tidak lagi dapat dijadikan pedoman bagi penegak hukum dalam sistem peradilan pidana. ${ }^{39}$ Namun pandangan yang berbeda disampaikan oleh Dworkin yang mengatakan bahwa hukum itu selalu interpretif, dan juga kebekuan tekstual hukum itu sangat mungkin dicairkan sehingga menjadi perdebatan dan menunjukkan realitas yang melee $^{\prime \prime}{ }^{40}$ Oleh sebab itulah hukum acara pidana ini yang bersifat sebagai hukum statis yang hanya memedulikan kepastian hukum, dan juga terjebak pada kepastian teks hukum semata, sehingga pada akhirnya harus diruntuhkan dengan cara diperbaharuhi. ${ }^{41}$

38 Jeremy betham, Teori Perundang-Undangan, Prinsip-Prinsip Hukum Perdata dan Hukum Pidana (The Theory of Legislation), diterjemahkan oleh Nurhadi, MA, Nusamedia, Bandung, 2010, hlm. 17

${ }^{39}$ Fence M. Wantu, “Antinomi Dalam Penegakan Hukum Oleh Hakim”, Jurnal Berkala Mimbar Hukum, Vol. 19 No. 3 Oktober 2007, Fakultas Hukum Universitas Gadjah Mada, Yogyakarta, hlm. 395

40 Ronald Dworkin, Law's Empire, The Belknap Press of Harvad University Press, Cambridge, 1986, p. $225-227$

${ }^{41}$ Op. Cit., Muhammad Rustamaji, Pembaharuan Hukum Acara Pidana.., hlm. 5 
Revitalisasi merupakan proses, cara dan perbuatan yang menghidupkan kembali suatu hal yang sebelumnya kurang terberdaya, secara sederhananya menjadikan sesuatu atau perbuatan menjadi vital. Dalam konteks ini berarti bahwa upaya hukum kasasi demi kepentingan hukum yang dulunya kurang efektif akan di efektifkan lagi atau dengan kata lain menghidupkan kembali di masa yang akan datang. Sebagaimana telah dijelaskan di pembahasan sebelumnya bahwa upaya hukum kasasi demi kepentingan hukum yang tidak berjalan efektif bukan disebabkan karena minimnya perkara yang masuk akan tetapi permasalahan terletak dalam KUHAP yakni pada frasa "tidak akan merubah putusan pengadilan", sehingga tidak terciptanya keadilan, kemanfaatan dan kepastian hukum. Oleh sebab itulah agar instrumen ini dapat berjalan secara efektif kedepannya perlu dilakukan pembaharuan hukum acara pidana.

Barda Nawawi Arief mengatakan bahwa pembaharuan hukum acara pidana pada hakikatnya merupakan bagian dari upaya rasional, mengefektifkan penegakan hukum melalui memperbaiki legal substance.42 Artinya, tujuan pembaharuan hukum tidak terpaku kepada hukum materiil saja melainkan juga hukum acara yang harus diperbaharui. Pembaharuan hukum di sektor hukum acara pidana tersebut merupakan bagian dari pembangunan hukum nasional guna mengatasi berbagai permasalahan dalam rangka penegakan hukum, yakni mengenai proses penyelesaian perkara pidana yang berkeadilan. Namun disamping itu juga bertujuan untuk merevitalisasi peraturan perundangundangan yang tumpang tindih, disharmoni dan multitafsir ${ }^{43}$, serta tambahan dari penulis berupa agar ketentuan didalam KUHAP bisa berjalan efektif seperti upaya hukum luar biasa yakni kasasi demi kepentingan hukum.

Merevitalisasi kembali Kitab Hukum Acara Pidana bertujuan agar upaya hukum luar biasa yakni kasasi demi kepentingan hukum dapat berjalan efektif sehingga dapat digunakan sebagaimana mestinya, yaitu dengan cara mengembalikan hak upaya hukum kasasi demi kepentingan hukum kepada Jaksa Penuntut Umum, serta mengubah atau merevisi pasal yang menjadi akar permasalahan ketidakefektifan tersebut, agar Kitab Undang-Undang Hukum Acara Pidana kedepanya dapat berjalan efektif, serta Penuntut Umum tidak lagi keluar dari kewenanganya.

Di dalam merancang atau membentuk undang-undang yang akan datang, perlu kiranya memerhatikan asas-asas dalam pembentukan peraturan perundang-undangan yakni kejelasan tujuan, kelembagaan atau organ

42 Yaris Adhial Fajrin dan Ach. Faisol Triwijaya, "Arah Pembaharuan Hukum Pidana di Tengah Pluralisme Hukum Indonesia”, Jurnal Penelitian Hukum dan Pendidikan, Vol.18 No.1, 2019, hlm. 736

43 Apri Listiyanto, "Pembaharuan Sistem Hukum Acara Pidana", Jurnal Rechts Vinding, 2017, hlm. 2 
pembentuk yang tepat, kesesuaian antara jenis dan materi muatan, dapat dilaksanakan, kedayagunaan dan kehasilgunaan, kejelasan rumusan, serta keterbukaan. ${ }^{44}$ Itikad serta tujuan yang hendak dicapai dengan terdapatnya pembaruan substansi peraturan perundang-undangan pada intinya merupakan guna menyempurnakan mekanisme penegakan hukum oleh aparat penegak hukum agar tercapai tujuan yang berkepastian, berguna dan melindungi prinsip serta nilai keadilan.

Pembahasan di atas menunjukkan bahwa pembaharuan hukum acara pidana harus berpedoman pada pembentukan dan penyusunan yang baik dan benar yaitu memenuhi kriteria-kriteria diatas sehingga dapat mewujudkan keadilan, kemanfaatan, dan kepastian hukum. Lahirnya hukum acara pidana yang akan datang (modern) sudah lama didambakan oleh semua orang, termasuk jaksa penuntut umum, supaya dapat mewujudkan supremasi hukum yang sesuai dengan Pancasila dan Undang-Undang Dasar 1945 sehingga membangkitkan optimisme harapan yang lebih baik dalam penegakan hukum. 45

\section{Penutup}

Hasil penelitian ini menyimpulkan bahwa pertama, upaya hukum berupa kasasi demi kepentingan hukum tidak berjalan secara efektif jika dibandingkan dengan upaya hukum lainnya. Hal ini ditegaskan dengan fakta bahwa kasasi demi kepentingan hukum hanya dilakukan dalam dua putusan yakni putusan No. 186 K/Kr/1979 dan putusan No. 1828 K/Pid/1989, dimana putusan kasasi demi kepentingan hukum tidak boleh merugikan pihak terpidana sehingga putusan pengadilan yang berupa pemidanaan, pembebasan atau pelepasan dari segala tuntutan hukum, tidak akan berubah. Oleh karena itu, Jaksa Penuntut Umum lebih cenderung menggunakan upaya hukum luar biasa yakni peninjauan kembali.

Kedua, efektivitas kasasi demi kepentingan hukum dapat terwujud jika dilakukan pembaharuan hukum acara pidana, khususnya terkait revitalisasi atau mengembalikan hak upaya hukum kasasi demi kepentingan hukum kepada jaksa penuntut umum. Selain itu, pembaharuan atas ketentuan atau pasal di dalam Kitab Undang-Undang Hukum Acara Pidana (KUHAP) yang menjadi penyebab ketidakefektifan tersebut perlu dilakukan agar tercipta efektivitas penegakan hukum pidana secara umum tanpa mengurangi kewenangan jaksa penuntut umum.

44 Pasal 5 Undang-Undang Nomor 12 Tahun 2011 tentang Pembentukan Peraturan Perundang-

45 M. Zen Abdullah, "rgensi Perlunya Pembaharuan Hukum Acara Pidana Nasional di Indonesia Yang Lebih Responsif”, Jurnal Ilmiah Universitas Batanghari Jambi, Vol.20 No.1, 2020, hlm. 284 


\section{Daftar Pustaka}

\section{Buku}

Aflah, R. N., Barang Bukti Dalam Proses Pidana, Sinar Grafik, Jakarta, 2002. Kapita Selekta Hukum Pidana Tentang Sistem Peradilan Pidana Terpadu, BP Universitas Diponegoro, Semarang, 2007.

Chazawi, A., Lembaga Peninjauan (PK) Perkara Pidana (Penegakan Hukum Dalam Penyimpangan Praktik \& Peradilan Sesat), Sinar Grafika, Jakarta, 2011.

Dahlan, Problematika Keadilan Dalam Penerapan Pidana Terhadap Penyalahgunaan Narkotika, Deepublish, Yogyakarta, 2007.

Dworkin, R. Law's Empire, The Belknap Press of Harvad University Press, Cambridge, 1986.

Hamzah, A., \& Dahlan, I., Upaya-Upaya Hukum Dalam Perkara Pidana, Bina Aksara, Jakarta, 1987.

Harahap, M. Y., Pembahasan Permasalahan dan Penerapan KUHAP, Pemeriksaan Sidang Pengadilan, Banding, Kasasi, Peninjauan Kembali, Sinar Grafika, Jakarta, 2017.

Marbun, R., Bram, D., \& dkk., Kamus Hukum Lengkap, Transmedia Pustaka, Jakarta, 2012

Marzuki, P. M., Penelitian Hukum, Kencana, Jakarta, 2009.

MD, M. M., Membangun Politik Hukum, Menegakkan Konstitusi, Pustaka LP3ES, Jakarta, 2006.

Moeljatno, Azaz-Azaz Hukum Pidana, Bina Aksara, Jakarta, 2006.

Purwoleksono, D. E., Hukum Acara Pidana, Airlangga University Press, Surabaya, 2015.

Ramiyanto, Upaya-Upaya Hukum Perkara Pidana Di Dalam Hukum Positif dan Perkembangannya, Citra Aditya Bakti, Bandung, 2019.

Reksodiputro, M., Kriminologi dan Sistem Peradilan Pidana, Pusat Pelayanan Keadilan dan Pengabdian Hukum Universita Indonesia, Jakarta, 1994.

Sofyan, A., \& Asis, A., Hukum Acara Pidana Suatu Pengantar, Pranamedia Grup, Jakarta, 2014.

YLBHI dan PSHK, Panduan Bantuan Hukum di Indonesia, YLBHI, Jakarta, 2007

\section{Jurnal}

A. Listiyanto, "Pembaharuan Sistem Hukum Acara Pidana", Rechts Vinding, 2017.

Arsyah, A. M., Mulyani, C. K., \& dkk., "Kajian Labirin Hukum Penyelesaian Kasus Djoko Tjandra", Dewan Mahasiswa Juctica Fakultas Hukum UGM, Yogyakarta, 2020.

Fajrin, Y. A., \& Triwijaya, A. F., “Arah Pembaharuan Hukum Pidana di Tengah Pluralisme Hukum Indonesia", Penelitian Hukum dan Pendidikan, Vol. 18 No. 1, 2019. 
Konardi, M. S., U"paya Hukum Kasasi Demi Kepentingan Hukum di Indonesia", https://e-journal.uajy.ac.id/12142/1/Jurnal\%20HK11433.pdf (Universitas Atma Jaya), 2019.

M. Ali, "Sistem Peradilan Pidana Progresif: Alternatif Dalam Penegakan Hukum Pidana", Jurnal Hukum, Vol. 14, No. 2, 211, 2007.

M. Rustamaji, "Pembaharuan Hukum Acara Pidana Melalui Telaah Sisi Kemanusiaan Aparat Penegak Hukum", Kanun Ilmu Hukum, Vol. 19 No. 1, 2017.

M. Z. Abdullah, “Urgensi Perlunya Pembaharuan Hukum Acara Pidana Nasional di Indonesia Yang Lebih Responsif", Jurnal Ilmiah, Universitas Batanghari Jambi, Vol. 20 No. 1, 2020.

Ridwan, "Kebijakan Penegakan Hukum Pidana Dalam Pemberantasan Tindak Pidana Korupsi di Indonesia", Jure Humano, Volume Nomor 1, 2019.

\section{Tesisi}

R. Darmawan, “Upaya Hukum Luar Biasa Peninjauan Kembali Terhadap Putusan Bebas Dalam Perkara Pidana" Tesis, Universitas Indonesia, 2012.

\section{Peraturan Perundang-Undangan}

Undang-Undang Nomor 8 Tahun 1981 Tentang Kitab Undang-Undang Hukum Acara Pidana

Undang-Undang Nomor 12 Tahun 2011 Tentang Pembentukan Peraturan Perundang-Undangan

\section{Internet}

http://krupukulit.com/tinjauan-kritis-atas-kepala-kejaksaan-tinggi-dalam-upayahukumdi-dalam-ruu-kuhap. Akses 2 Januari 2021 